\title{
Illegal trade of the Psittacidae in Venezuela
}

\author{
Ada Sánchez-Mercado, Marianne Asmüssen, Jon Paul Rodríguez \\ Lisandro Moran, Arlene Cardozo-Urdaneta and lorena Isabel Morales
}

\begin{abstract}
Illegal wildlife trade is one of the major threats to Neotropical psittacids, with nearly $28 \%$ of species targeted for the illegal pet trade. We analysed the most comprehensive data set on illegal wildlife trade currently available for Venezuela, from various sources, to provide a quantitative assessment of the magnitude, scope and detectability of the trade in psittacids at the national level. We calculated a specific offer index ( $\mathrm{SO}$ ) based on the frequency of which each species was offered for sale. Forty-seven species of psittacids were traded in Venezuela during 1981-2015, of which 17 were non-native. At least 641,675 individuals were traded, with an overall extraction rate of 18,334 individuals per year (35 years of accumulated reports). Amazona ochrocephala was the most frequently detected species $(\mathrm{SO}=3.603)$, with the highest extraction rate $(10,544$ individuals per year), followed by Eupsittula pertinax $(\mathrm{SO}=1.357)$ and Amazona amazonica $(\mathrm{SO}=1.073)$. Amazona barbadensis, Ara ararauna and Ara chloropterus were the fourth most frequently detected species $(\mathrm{SO}=0.564-0.615)$. Eleven species were involved principally in domestic trade $(>60 \%$ of records). Our approach could be the first step in developing a national monitoring programme to inform national policy on the trade in psittacids. Patterns and numbers provided may be used to update the official list of threatened species, and could also be used in planning conservation actions.
\end{abstract}

Keywords Birds, conservation, illegal wildlife trade, parrots, pet trade, Venezuela

Supplementary material for this article is available at https://doi.org/10.1017/So03060531700120X

\section{Introduction}

Tlegal wildlife trade is one of the major threats to global 1 biodiversity, generating a black market valued at USD 5-20 billion per year (Wyler \& Sheikh, 2013). Most of this

\footnotetext{
Ada Sánchez-Mercado (Corresponding author), Lisandro Moran, Arlene CARdozo-URdaneta* Centro de Estudios Botánicos y Agroforestales, Instituto Venezolano de Investigaciones Científicas, Apartado 20632, Caracas 1020-A, Venezuela. E-mail asanchez@ivic.gob.ve/ay.sanchez.mercado@gmail.com

Marianne Asmüssen, Jon Paul Rodríguez Centro de Ecología, Instituto Venezolano de Investigaciones Científicas, Caracas, Venezuela

Lorena Isabel Morales Fundación Vida y Mar, Maracaibo, Venezuela

*Also at: Fundación Vida y Mar, Maracaibo, Venezuela

Received 23 February 2017. Revision requested 22 May 2017.

Accepted 25 July 2017. First published online 27 November 2017.
}

trade involves avian species, poached to supply both domestic and international demand for pets (Rosen \& Smith, 2010). Among birds, Neotropical psittacids are of primary conservation concern, with nearly $28 \%$ of species affected by poaching for the illegal pet trade (Olah et al., 2016).

The data used to measure the magnitude of the illegal pet trade in psittacids have come from four main sources: seizure records and surveys of trappers (Cantú Guzmán et al., 2007), literature reviews (Pires, 2012; Alves et al., 2013), direct observation in markets (Herrera \& Hennessey, 2007; Gastañaga et al., 2011; Silva Regueira \& Bernard, 2012), and observation of the proportion of nest cavities poached (Wright et al., 2001; Pain et al., 2006; Zager et al., 2009). Each source has a unique geographical and taxonomic coverage and evaluates different aspects of the market chain. Studies using a variety of sources are less frequent (Gavin et al., 2010), although a combination of sources could probably provide a better insight into the magnitude and scope of illegal activities, particularly in countries that lack the infrastructure to formally monitor illegal wildlife trade (Kaufmann et al., 2011).

In the Neotropics, Venezuela ranks second in psittacid species diversity (Rodríguez et al., 2015). Declining trends have been reported for 34 of the 50 psittacid species that occur there, and six are considered to be threatened (Supplementary Table S1). The primary threats to Venezuelan psittacids are capture for the pet trade (both domestic and international), and the destruction of nesting and feeding habitat by urban development (Rodríguez et al., 2015). Recent evidence suggests that even the most widespread psittacids of the genus Amazona may have undergone declines in their distribution (Ferrer-Paris et al., 2014). A previous review of trade in Venezuelan Psittacidae reported that at least 16 species were traded frequently, both domestically and internationally, and 12 of these were traded heavily (Desenne \& Strahl, 1991). However, with no quantitative measure of the capture frequency or extraction rates, the use of this information for monitoring purposes is limited. A more quantitative assessment, but with a local focus, estimated that Forpus passerinus, Eupsittula pertinax and Psittacara wagleri were the most frequently traded psittacids (Marín-Espinoza et al., 2011).

Here we analyse the most comprehensive data set on illegal wildlife trade currently available in Venezuela, gathered from various sources. We take into account data limitations and biases to provide a quantitative assessment of the magnitude, scope and detectability of the trade in 
psittacids at the national level. Specifically, we evaluate (1) the number of species involved in trade, (2) the magnitude of the trade in terms of number of reports per year and number of individuals traded per year, by species, and (3) the level of complementarity among data sources. Our approach of systematic data compilation from various sources, taking into account their limitations and heterogeneity, could be applicable in other countries with a tradition of commercial wildlife use and a lack of infrastructure for wildlife-use monitoring (Kaufmann et al., 2011).

\section{Methods}

\section{Study area and legal framework}

Our study area spans the entire Venezuelan territory (916.445 km² ; Aguilera et al., 2003). Wildlife administration is under the jurisdiction of the Ministry for Ecosocialism and Water (previously Venezuelan Environment Ministry) but law enforcement is carried out by the military and police, with the Ministry playing a supporting role (Ojasti, 1993). The country's law on wildlife use has not changed since 1970 (Congreso de la República de Venezuela, 1970) and, in general, wildlife use is permitted via special licenses, including for scientific sampling, pest control, and sport and commercial hunting. There is no distinction made between subsistence hunting and sport hunting. Wildlife take without a permit is punishable by fines and up to 2 years in prison; possession is penalized by seizure of the animal (República de Venezuela, 2012). Venezuela ratified CITES in 1977 and restricts exports of all native wildlife. Hunting of all psittacid species is banned, and the majority of psittacids are listed in Appendix II of CITES, with three (Amazona barbadensis, Ara macao and Ara militaris) listed in Appendix I (UNEP-WCMC, 2015). There are no captive-breeding or sustainable use programmes or government-sanctioned management plans for psittacids in Venezuela (Bigio et al., 1994; Morales \& Dessene, 1994).

\section{Study species}

Although the number of taxa within the family Psittacidae is relatively stable, their classification is uncertain (Joseph et al., 2012). We used the taxonomy of the IUCN Red List (IUCN, 2017), in which 50 psittacid species occurring in Venezuela are reported, from the genera Amazona (8), Pyrrhura (7), Ara (5), Pionus (5), Touit (4), Brotogeris (3), Forpus (3), Pyrilia (3), Psittacara (2), Aratinga (1), Deroptyus (1), Bolborhynchus (1), Diopsittaca (1), Eupsittula (1), Hapalopsittaca (1), Nannopsittaca (1), Orthopsittaca (1), Pionites (1) and Thectocercus (1), Thectocercus acuticaudatus, previously classified as Aratinga acuticaudata; Remsen et al., 2013). Four of these species are categorized as threatened (Supplementary Table $\mathrm{S} 1$ ).

\section{Data compilation}

We defined as illegal all take without permits of undomesticated terrestrial psittacid species from protected or private areas, including unlicensed harvesting of eggs or juveniles and domestic and international trade of live specimens (Sánchez-Mercado et al., 2016). We categorized records of illegal trade as domestic or international. The domestic trade category included records of whole specimens or their parts offered for sale or barter to local buyers, either directly by trappers or by intermediate dealers who obtained items from trappers or other local intermediates. The international trade category included sales by trappers or intermediates to buyers abroad (Sánchez-Mercado et al., 2016). We included all uses described for a given report; for example, if a trapper captured a parrot and sold it in a local market or to a neighbour, this was recorded as domestic trade, but if the trapper sold the parrot to a local intermediary, who then re-sold it to a Colombian buyer, this was recorded as both local and international trade.

We compiled 1,110 records of domestic and international trade of psittacids, from five sources: (1) national and international enforcement agencies, (2) the CITES trade database, (3) published and unpublished literature, (4) internet social networks, and (5) reports of donated and seized wildlife from national zoos.

Data from the first three sources were compiled by Sánchez-Mercado et al. (2016). Data from national enforcement agencies comprised 329 reports of seized wildlife at the national level for 1990-200o, provided by the Venezuelan Environment Ministry. According to Ministry personnel, in all cases their reports referred to national traders selling goods on international markets, and the final destination of specimens depended on the effectiveness and speed of response of international dealers. If international dealers delay, national traders try to sell their goods in domestic markets before the animals sicken or die (A. Martínez, pers. comm.; Sánchez-Mercado et al., 2016). Thus, we categorized the Ministry's records as domestic and international trade, to avoid underestimating international trade when the trade was detected at the national level.

Data from national enforcement agencies comprised 17 records from the U.S. Fish and Wildlife Service of seized wildlife from Venezuela during 1993-1998. CITES data (340 records) comprised wildlife and wildlife products seized from Venezuela during 1975-2015. Literature data (140 records) were compiled from national and international published and grey literature, from five online databases: ISI Web of Knowledge, Scirus, JSTOR, Google Scholar, and Zoological Record. We focused on ecology, conservation and anthropology journals, and used keywords in English and Spanish related to psittacid trade: Venezuela, poach, hunt, harvest, trade, and traffic. We also consulted the website of TRAFFIC, the wildlife trade monitoring network 
(TRAFFIC, 2008). To search the grey literature we requested support from Red Ara Venezuela, a network of Venezuelan environmental NGOs, to source internal reports and psittacid trade records from NGOs, consulted the websites of national ecology and ornithology conferences to find relevant abstracts, and asked wildlife managers and ornithologists for information and for additional contacts who might have information about psittacid trade.

We asked the Venezuelan Association of Zoos and Aquariums for records of psittacids handed over by members of the public (former pets that were no longer wanted) or those confiscated by authorities and placed in zoos. However, we received information for only two of the 16 private and public zoos in Venezuela (Ministerio del Poder Popular para el Ambiente, 2014), Bararida Zoo in Barquisimeto and Metropolitan Zoo in Maracaibo, for which we obtained a total of 117 records for 2010-2014 (Supplementary Table S1).

We monitored the activity of national Facebook groups during January 2016-May 2017. Using the keywords wildlife sale, animal sale, bird sale, and aviary, we identified 31 groups (10 public and 21 closed), and we monitored the weekly activity of the 10 public groups. For each post we recorded the link, publication date, city of publication, type of post (offer or demand), number of specimens offered for sale, sex and development stage of specimens (adult, fledgling), and the price (and currency). Taxonomic identification of species was based on images and the common name and description provided in the post, using Hilty (2003) as a guide for morphological characteristics. When identification at species level was not possible we used broader taxonomic categories (genus or family). We validated common and scientific names (considering synonyms, alternative spellings and subspecies) using the Encyclopedia of Life (2017). We obtained 167 reports of parrot trade.

Within each of the above sources we considered a record as a single observation in time of a unique combination of the following information: (1) location, (2) observation date, (3) species involved, (4) sex and development stage, and (5) quantity reported (number of specimens).

\section{Analysis}

We summarized the number of specimens recorded by species $\left(O_{i}\right)$, and calculated a specific offer index (SO) for each species based on how frequently it was offered for sale (Marín-Espinoza et al., 2011):

$$
S O=\left(O_{i} / O_{t}\right) \times(m / t) \times 100,
$$

where $O_{i}$ is the number of sales of individuals of species $i$ per year (i.e. number of records), $O_{t}$ the total number of species traded illegally, $m$ the number of years when species $i$ was offered for sale, and $t$ the total period of study (i.e. 35 years, 1981-2015). However, given the spatial, temporal and taxonomic biases in the data, this index cannot be interpreted as an accurate estimate of offer, but as an index of detectability (i.e. how frequently the sale of a given species is detected). We also calculated an extraction rate by species, as the number of specimens sold per year.

To evaluate complementarity among sources, we summarized the number of records and species obtained from each source according to type of trade (domestic or international). We also calculated Cohen's kappa $(\kappa)$ as an index of intersource agreement in species detected (i.e. inter-source reliability), using the function kappa2 in package irr in $R v .3 .3 .2$ ( $\mathrm{R}$ Development Core Team, 2015). Cohen's kappa ranges from -1 to +1 , where o represents the amount of agreement that can be expected from random chance, and 1 represents perfect agreement between the sources (McHugh, 2012).

To visualize temporal variation in the detection of psittacid trade, we plotted the accumulated number of records by year for the four most detected species. We also plotted the accumulated number of records of domestic and international trade by year.

\section{Results}

\section{Complementarity of sources}

In total, we detected 47 species of psittacids traded in Venezuela, of which 17 were non-native, apparently traded from Africa, Central America, the Caribbean, USA and other South American countries (Supplementary Table S1).

The most complete sources regarding number of species detected were CITES and the zoos, accounting for 29 and 28 species, respectively (Table 1 ). In general, agreement between sources regarding the species detected was low $(\kappa<0.5)$, with the highest complementarity between the literature and the Venezuelan Environment Ministry $(\kappa=0.259)$, followed by the literature, zoos and CITES ( $\kappa$ values 0.114-0.102), and the Environment Ministry, Facebook, zoos and CITES ( $\kappa$ values 0.119-0.198; Table 2). The sources with the lowest levels of complementarity with other sources were the zoos and CITES (Table 2). Zoos were the only source reporting trade for Agapornis personata, Amazona leucocephala, Aratinga jandaya, Aratinga leucophtalmus, Pionus chalcopterus, Pionus fuscus and Pyrrhura lepida. CITES was the only source reporting trade of Amazona aestiva, Amazona autumnalis, Brotogeris chrysoptera and Psittacara mitratus (Supplementary Table S1). In general, sources tend to focus on one type of trade, but literature review and the Environment Ministry provided records for both domestic and international trade (Table 1).

\section{Magnitude and scope of illegal trade}

The 1,110 records of illegal trade corresponded to 641,675 specimens, with an overall extraction rate of 18,334 
TABLE 1 The number of records of psittacids in the illegal trade in Venezuela, with the numbers of specimens and species recorded, from various sources. The number of records reporting domestic or international trade are also shown.

\begin{tabular}{lcccrr}
\hline Source & Number of records & Number of specimens & Number of species & Domestic & International \\
\hline Literature review & 140 & 2,419 & 22 & 139 & 19 \\
Venezuelan Environment Ministry & 329 & 2,220 & 23 & 329 & 329 \\
U.S. Fish \& Wildlife Service & 17 & 60 & 11 & 0 & 17 \\
Facebook & 167 & 258 & 25 & 160 & 2 \\
Zoos & 117 & 343 & 29 & 117 & 0 \\
CITES & 340 & 636,375 & & 340 \\
Total & 1,110 & 641,675 & & \\
\hline
\end{tabular}

TABLE 2 Inter-source reliability regarding the recording of psittacid species traded illegally in Venezuela, with Cohen's kappa ( $\kappa)$ for each pair of sources.

\begin{tabular}{|c|c|c|c|c|c|c|}
\hline & Literature & $\begin{array}{l}\text { Venezuelan Environment } \\
\text { Ministry }\end{array}$ & $\begin{array}{l}\text { U.S. Fish \& Wildlife } \\
\text { Service }\end{array}$ & Facebook & Zoo & CITES \\
\hline Literature & 1.000 & 0.259 & -0.020 & 0.072 & 0.102 & 0.114 \\
\hline $\begin{array}{l}\text { Venezuelan Environment } \\
\text { Ministry }\end{array}$ & & 1.000 & 0.043 & 0.119 & 0.124 & 0.198 \\
\hline U.S. Fish \& Wildlife Service & & & 1.000 & 0.051 & -0.090 & -0.001 \\
\hline Facebook & & & & 1.000 & 0.034 & -0.001 \\
\hline Zoo & & & & & 1.000 & 0.015 \\
\hline CITES & & & & & & 1.000 \\
\hline
\end{tabular}

individuals per year (35 years of accumulated reports). Amazona ochrocephala was the most frequently detected species $(\mathrm{SO}=3.603)$, with the highest extraction rate (10,544 individuals per year). The second and third most frequently detected species, E. pertinax and Amazona amazonica, had similar frequencies of detection $(\mathrm{SO}=1.357$ and 1.073); however, the number of $A$. amazonica individuals traded per year was almost 30 times higher (Supplementary Table S1). Ara ararauna, A. barbadensis and A. chloropterus were the fourth most frequently detected species ( $\mathrm{SO}=0.564-0.615$ ), but the number of individuals of $A$. barbadensis traded was 10 times lower than the other two species. Although the trade of F. passerinus and A. macao was detected less frequently than the other species, it involved at least as many individuals as of $A$. amazonica (c. 20.00o; Table 2).

The majority of species (13) were traded principally in the domestic market $(>60 \%$ of records were related to domestic trade). Ten species were reported to be traded in similar proportions in the domestic and international markets (40-60\% of records; A. amazonica, A. barbadensis, Amazona dufresniana, A. chloropterus, A. macao, A. militaris, Diopsittaca nobilis, Thectocercus acuticaudatus, Nannopsittaca panychlora and Pionus menstruus). A similar number of species were traded predominantly in the international market ( $>80 \%$ of records; A. aestiva, Amazona albifrons, A. autumnalis, Amazona bodini, A. ochrocephala, A. ararauna, A. macao, Psittacara mitrata, Brotogeris chrysopterus and Pionus tumultuosus; Table 2).

In general, the number of records increased over time, with international trade being the most frequently detected
(Fig. 1a). The number of records of A. ochrocephala increased sharply after 1995, whereas there was a steady increase in the number of records of the other three most frequently detected species (Fig. 1b).

\section{Discussion}

The illegal trade of psittacids in Venezuela has been a longstanding threat, with domestic and international trade spanning 35 years and involving 54\% (30 species) of the psittacid species occurring in the country as well as 17 non-native species. The number of traded species reported here is lower than in previous reports (e.g. 36 species reported by Desenne \& Strahl, 1991), but our findings are based on reliable quantitative data and not only on qualitative expert assessments. Of the six species for which trade was reported previously but did not occur in our data, five (Amazona mercenaria, Pionopsitta caica, Pionopsitta barrabandi, Pyrrhura hoematotis and Pyrrhura picta) were categorized as low level of trade by Desenne \& Strahl (1991), although the authors did not report the frequency of trade. The other species that did not occur in our data but had a high level of trade according to Desenne \& Strahl (1991) was Touit batavica. There are two probable explanations for this nondetected trade: the frequency of trade is too low to be detected, or geographical biases in our data sources limit our capacity to detect species with more restricted distributions. A systematic sampling covering ecosystems and bioregions throughout the country is needed to discern between these two possibilities. 

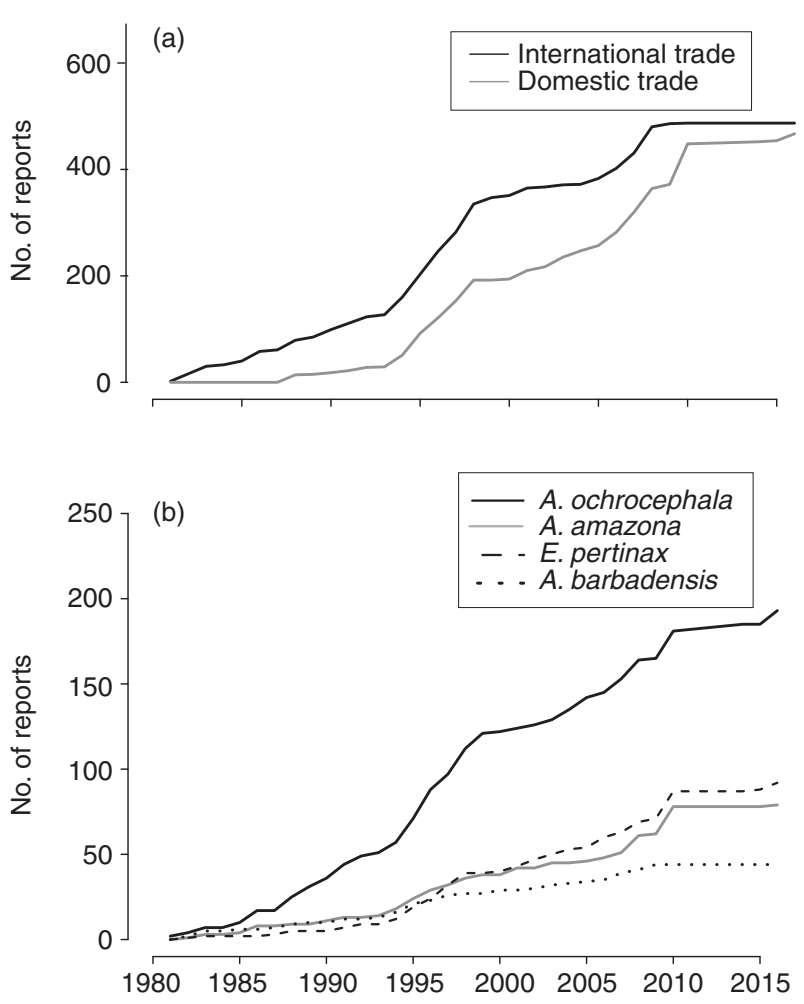

FIG. 1 Number of accumulated records of illegal psittacid trade in Venezuela by year (a) by type of trade and (b) by number of records of the four most frequently detected species.

As expected, each source complemented the figure for the number of species involved in trade. The fact that national zoos accounted for $63 \%$ of detected species highlights their importance in monitoring illegal wildlife trade. In Venezuela, as in other South American countries, zoos are offered animals by members of the public and are required to receive animals confiscated by the authorities, and thus are an important source of information about domestic wildlife trade (Cuarón, 2005).

Although we are confident in our estimation of the number of psittacid species traded, based on the accumulation of reports over 35 years, our findings on the magnitude of trade is clearly an underestimation. Quantitative assessments of psittacid trade in Mexico (Cantú Guzmán et al., 2007) and Bolivia (Herrera \& Hennessey, 2007) indicate that only $2-20 \%$ of parrot trade is detected by enforcement patrols. Underestimation of the magnitude of trade was evident in our various data sources: combined, records from the literature, zoos and seizures accounted for only $<_{1} \%$ of the number of specimens traded, whereas CITES data accounted for $99 \%$. This suggests that international trade is more important than domestic trade (all CITES records were of international trade), but we suspect this result reflects the limited capacity of law enforcement at the national level rather than a real pattern. For example, barely $12 \%$ of records of $A$. ochrocephala were detected at national level, although this is the most sought after species for the pet trade because of its ability to imitate the human voice (Desenne et al., 1994). Furthermore, evidence from Mexico, Peru, Bolivia and Brazil indicates that the illegal parrot trade is largely domestic (Herrera \& Hennessey, 2007; Gastañaga et al., 2011; Silva Regueira \& Bernard, 2012).

Both the domestic and international illegal trade of psittacids in Venezuela are focused on widespread and abundant species (A. ochrocephala, E. pertinax and A. amazonica), supporting the notion that the trade is opportunistic in nature (Silva Regueira \& Bernard, 2012). Previous studies have posited that at least 12 species, including macaws (i.e. A. ararauna and A. chloropterus) and parakeets (i.e. T. acuticaudatus and E. pertinax), are subject to equivalent trade intensity (Gastañaga et al., 2011; Pires, 2012). The frequency of trade in A. ochrocephala was seven times higher than for macaws, and the number of specimens traded was 3-17 times higher. The effect of this extraction rate on the distribution range and population viability of A. ochrocephala requires evaluation.

The species affected by international trade were not the same as those affected by domestic trade. For international markets, large parrots (five Amazona species), including the widespread and common A. ochrocephala, and large macaws (two Ara species) are exported from Venezuela. This finding supports the notion that the most attractive species (large body size, colourful and with the ability to imitate human speech), such as amazons and macaws, are more likely to be exported (Desenne \& Strahl, 1991). Half of the species involved in international trade were not native to Venezuela (e.g. A. albifrons, A. aestiva, P. mitratus and $P$. tumultuosus), suggesting that Venezuela could be an important transit country for the trade in parrot species from Central America and other South American countries. The domestic market was more focused on parakeets (Aratinga and Brotogeris spp.), small parrots (Pionus spp.) and parrotlets (Forpus spp.). Species traded in both domestic and international markets were mostly large parrots (including the threatened A. barbadensis, and A. amazonica), large macaws (A. chloropterus and A. militaris) and small parrots (Aratinga spp. and Pionus spp.).

Our approach of compiling and systematizing information about illegal trade in psittacids from various sources should be taken as the first step to develop a national monitoring programme to inform national policy on illegal wildlife trade. The patterns and numbers provided could be used to update the official list of threatened species in Venezuela, which currently includes four psittacids (A. barbadensis, $T$. acuticaudatus, A. militaris and Hapalopsittaca amazonina; Rodríguez et al., 2015). This baseline information could also be used to plan effective conservation actions, taking into account budget constraints and the limited infrastructure for wildlife-use monitoring and law enforcement (Briceño-Linares et al., 2011). 


\section{Acknowledgements}

Funds for this research were provided by Instituto Venezolano de Investigaciones Científicas (Project number 1071). We are grateful to H. Guada, P. Vernet, E. Zent, A. Martínez, A. Fallabrino, D. Giraldon, A.S. Boher, F. Rojas-Suárez, R. Calchi, E. Mujica, A. Cardozo, I. Villasmil, A.C. Molina, P. Ortega, J. Larreal, M.D. Rincón, D. Muller, K. Muller, T. Barros and J. Ferrebuz for providing technical reports, theses and other grey literature that was not available through online searches. We also thank Provita, Venezuela, and the IUCN Species Survival Commission (SSC), Switzerland, for providing institutional support.

\section{Author contributions}

ASM conceived and designed the research, compiled and analysed the data, and co-wrote the article. JPR compiled the data and co-wrote the article. MA, LM, ACU and LIM compiled the data.

\section{References}

Aguilera, M., Azócar, A. \& González-Jiménez, E. (2003) Biodiversidad en Venezuela. Tomo I y II. Fundación Polar. Ministerios de Ciencia y Tecnología. Fondo Nacional de Ciencia, Tecnología e Innovación, Caracas, Venezuela.

Alves, R.R.N., Lima, J.R.F. \& Araujo, H.F.P. (2013) The live bird trade in Brazil and its conservation implications: an overview. Bird Conservation International, 23, 53-65.

Bigio, D., Luy, A. \& Sierra, J. (1994) Aspectos legales relacionados con la conservación de los psitácidos en Venezuela. In Biología y conservación de los psitácidos de Venezuela (eds G. Morales, I. Novo, D. Bigio, A. Luy \& F. Rojas-Suárez), pp. 281-283. Revista Papagaien, The Nature Conservancy, The Wildlife Conservation Society, Wild Wings Underhill Foundation \& Provita, Caracas, Venezuela.

Briceño-Linares, J.M., Rodríguez, J.P., Rodríguez-Clark, K.M., Rojas-Suárez, F., Millán, P.A., Vittori, E.G. \&

Carrasco-Muñoz, M. (2011) Adapting to changing poaching intensity of Yellow-Shouldered Parrot (Amazona barbadensis) nestlings in Margarita Island, Venezuela. Biological Conservation, $144,1188-1193$.

Cantú Guzmán, J.C., Sánchez Saldaña, M.E., Grosselet, M. \& Silva Gamez, J. (2007) The Illegal Parrot Trade in Mexico. A Comprensive Assessment. Defenders of Wildlife, Mexico City, Mexico.

Congreso de la República de Venezuela (1970) Ley de protección a la fauna silvestre. Gaceta Oficial Nro 29.289, Caracas, Venezuela.

CUARÓN, A.D. (2005) Further role of zoos in conservation: monitoring wildlife use and the dilemma of receiving donated and confiscated animals. Zoo Biology, 24, 115-124.

Desenne, P., Strahl, S., Morales, G., Novo, I., Bigio, D., Luy, A. \& Rojas-SuÁrez, F. (1994) Situación poblacional y jerarquización de especies para la conservación de la familia Psittacidae en Venezuela. In Biología y conservación de los psitácidos de Venezuela (eds G. Morales, I. Novo, D. Bigio, A. Luy \& F. Rojas-Suárez), pp. 231-272. Revista Papagaien, The Nature Conservancy, The Wildlife
Conservation Society, Wild Wings Underhill Foundation \& Provita, Caracas, Venezuela.

Desenne, P. \& Strahl, S.D. (1991) Trade and the conservation status of the family Psittacidae in Venezuela. Bird Conservation International, 1, 153-169.

Encyclopedia of Life (2017) Http://www.eol.org/ [accessed 1o May 2016].

Ferrer-Paris, J.R., Sánchez-Mercado, A., Rodríguez-Clark, K. M., Rodríguez, J.P. \& Rodríguez, G.A. (2014) Using limited data to detect changes in species distributions: insights from Amazon parrots in Venezuela. Biological Conservation, 173, 133-143.

Gastañaga, M., Macleod, R., Hennessey, B., Núñez, J.U., Puse, E., Arrascue, A. et al. (2011) A study of the parrot trade in Peru and the potential importance of internal trade for threatened species. Bird Conservation International, 21, 76-85.

Gavin, M.C., Solomon, J.N. \& Blank, S.G. (2010) Measuring and monitoring illegal use of natural resources. Conservation Biology, 24, 89-100.

Herrera, M. \& Hennessey, B. (2007) Quantifying the illegal parrot trade in Santa Cruz de la Sierra, Bolivia, with emphasis on threatened species. Bird Conservation International, 17, 295-300.

Hilty, S.L. (2003) Birds of Venezuela. 2nd edition. Princeton University Press, Princeton, USA.

IUCN (2017) The IUCN Red List of Threatened Species 2017-1. Http://www.iucnredlist.org/ [accessed 23 August 2017].

Joseph, L., Toon, A., Schirtzinger, E.E., Wright, T.F. \& SCHOdDE, R. (2012) A revised nomenclature and classification for family-group taxa of parrots (Psittaciformes). Zootaxa, 3205, 26-40.

Kaufmann, D., Kraay, A. \& Mastruzzi, M. (2011) The Worldwide Governance Indicators: methodology and analytical issues. Hague Journal on the Rule of Law, 3, 220-246.

Marín-Espinoza, G., Guevara-Vallera, S., Prieto-Arcas, A., Muñoz-Gil, J. \& Carvajal-Moreno, Y. (2011) Comercialización ilegal de aves silvestres: Un caso en Venezuela. The Biologist, 9, $38-52$.

MCHugh, M.L. (2012) Interrater reliability: the kappa statistic. Biochemia Medica, 22, 276-282.

Ministerio del Poder Popular para el Ambiente (2014) Plan estratégico nacional de zoológicos, acuarios y centros afines de la República Bolivariana de Venezuela (PENZA) (eds H. González, G. Sánchez, I. Morales, J. Valera \& V. Gómez). Fundación Nacional de Parques Zoológicos y Acuarios \& Oficina Nacional de Diversidad Biológica, Caracas, Venezuela.

Morales, G. \& Dessene, P. (1994) Plan de acción y conservación de los psitácidos venezolanos. In Biología y conservación de los psitácidos de Venezuela (eds G. Morales, I. Novo, D. Bigio, A. Luy \& F. Rojas-Suárez), pp. 299-307. Revista Papagaien, The Nature Conservancy, The Wildlife Conservation Society, Wild Wings Underhill Foundation \& Provita, Caracas, Venezuela.

OjAsti, J. (1993) Utilización de la fauna silvestre en América Latina. Situación y perspectiva para un manejos sostenible. Guía FAO Conservación 25. Food and Agriculture Organization of the United Nations, Rome, Italy.

Olah, G., Butchart, S.H.M., Symes, A., Guzmán, I.M., Cunningham, R., Brightsmith, D.J. \& Heinsohn, R. (2016) Ecological and socio-economic factors affecting extinction risk in parrots. Biodiversity and Conservation, 25, 205-223.

Pain, D.J., Martins, T.L.F., Boussekey, M., Diaz, S.H., Downs, C. T., Екsт вом, J.M.M. et al. (2006) Impact of protection on nest take and nesting success of parrots in Africa, Asia and Australasia. Animal Conservation, 9, 322-330.

PIRES, S.F. (2012) The illegal parrot trade: a literature review. Global Crime, 13, 176-190. 
R Development Core Team (2015) R: A Language and Environment for Statistical Computing. R Foundation for Statistical Computing, Vienna, Austria.

Remsen, Jr, J.V., Schirtzinger, E.E., Ferraroni, A., Silveira, L.F. \& WRIGHT, T.F. (2013) DNA-sequence data require revision of the parrot genus Aratinga (Aves: Psittacidae). Zootaxa, 3641, 296-300.

República de Venezuela (2012) Ley penal del ambiente. Gaceta oficial $\mathrm{N}^{\mathrm{o}} 39.913$, Caracas, Venezuela.

Rodríguez, J.P., García-Rawlins, A. \& Rojas-Suárez, F. (2015) Libro rojo de la fauna venezolana. Provita \& Fundación Empresas Polar, Caracas, Venezuela.

Rosen, G.E. \& S Mith, K.F. (2010) Summarizing the evidence on the international trade in illegal wildlife. EcoHealth, 7, 24-32.

Sánchez-Mercado, A., Asmússen, M., Rodríguez-Clark, K.M., RodrígueZ, J.P. \& JedrZejewski, W. (2016) Using spatial patterns in illegal wildlife uses to reveal connections between subsistence hunting and trade. Conservation Biology, 30, 1222-1232.

Silva Regueira, R.F. \& BERNARD, E. (2012) Wildlife sinks: quantifying the impact of illegal bird trade in street markets in Brazil. Biological Conservation, 149, 16-22.

TRAFFIC (2008) Http://www.traffic.org/ [accessed 5 February 2015].

UNEP-WCMC (UNEP World Conservation Monitoring Centre) (2015) Checklist of CITES Species. Http://checklist.cites. org. [accessed 10 March 2015].

Wright, T.F., Toft, C.A., Enkerlin-Hoeflich, E., Gonzalez-Elizondo, J., Albornoz, M., Rodríguez-Ferraro,
A. et al. (2001) Nest poaching in Neotropical parrots. Conservation Biology, 15, 710-720.

Wyler, L.S. \& Sheikh, P.A. (2013) International Illegal Trade in Wildlife: Threats and U.S. Policy. Congressional Research Service RL34395. The Library of Congress, Washington, DC, USA.

Zager, I., Rodriguez-Clark, K.M., Eberhard, J.R., Rodriguez, J. P. \& Millán, P.A. (2009) Nest poaching in the Venezuelan insular subspecies of the brown-throated parakeet (Aratinga pertinax).

Ornitología Neotropical, 20, 99-112.

\section{Biographical sketches}

Ada SÁncheZ-Mercado works on conservation biology projects on vertebrates and invertebrates throughout Venezuela, with an emphasis on modelling and quantitative ecology. Marianne Asmússen researches the conservation of threatened species and ecosystems. Jon PAUL Rodríguez works on the conservation of Venezuelan species and ecosystems, and is currently Chair of the IUCN Species Survival Commission. LISANDRO MORAN is an ornithologist with interests in ecology, natural history, and conservation of threatened bird species. ARLENE CARDOZO-URDANETA is a biologist with experience in the reproductive ecology of anurans, bioacoustics and conservation biology. LORENA ISABEL MORALes is a veterinarian with interests in wildlife conservation and management. She collaborates with Venezuelan NGO Fundación Vida y Mar in environmental education. 